Check for updates

Cite this: Chem. Sci., 2019, 10, 6457

๑ All publication charges for this article have been paid for by the Royal Society of Chemistry

\title{
Stereoisomerism of stapled peptide inhibitors of the p53-Mdm2 interaction: an assessment of synthetic strategies and activity profiles $\dagger$
}

\author{
Tsz Ying Yuen, (D) *a Christopher J. Brown, ${ }^{\mathrm{b}}$ Yuezhen Xue, ${ }^{\mathrm{b}}$ Yaw Sing Tan, ${ }^{\mathrm{c}}$ \\ Fernando J. Ferrer Gago, ${ }^{\mathrm{b}}$ Xue Er Lee, ${ }^{\mathrm{b}} \mathrm{Jin}$ Yong Neo, ${ }^{\mathrm{a}}$ Dawn Thean, ${ }^{\mathrm{b}}$ \\ Hung Yi Kristal Kaan, ${ }^{d}$ Anthony W. Partridge, (D) ${ }^{d}$ Chandra S. Verma, (D)c \\ David P. Lane (D) ${ }^{b}$ and Charles W. Johannes (D) ${ }^{a}$
}

Received 25th March 2019 Accepted 19th May 2019

DOI: 10.1039/c9sc01456j

rsc.li/chemical-science

\begin{abstract}
All-hydrocarbon, $i, i+7$ stapled peptide inhibitors of the p53-Mdm2 interaction have emerged as promising new leads for cancer therapy. Typical chemical synthesis via olefin metathesis results in the formation of both $E$ - and Z-isomers, an observation that is rarely disclosed but may be of importance in targeting PPI. In this study, we evaluated the effect of staple geometry on the biological activity of five p53-reactivating peptides. We also present strategies for the modulation of the $E / Z$ ratio and attainment of the hydrogenated adduct through repurposing of the metathesis catalyst.
\end{abstract}

\section{Introduction}

Short peptides often lack well-defined secondary structures when excised from the native protein environment. In order to retain the native conformation of the peptide, chemists have rationally developed a myriad of cyclisation strategies. One such method relies on the use of distance-matching tethers that covalently link two amino acid side chains (e.g. Cys, ${ }^{1-9}$ Lys, ${ }^{10-15}$ Trp ${ }^{16-18}$ and Met $^{19}$ ). Alternative stabilisation strategies such as alkene, ${ }^{20-25}$ oxime ${ }^{26,27} 1,2,3$-trizole ${ }^{28-30}$ hydrazide, ${ }^{31}$ alkyne, ${ }^{32}$ spiropyran ${ }^{33}$ as well as mixed cross-linkages have also been published. ${ }^{34,35}$ The resultant macrocycles often possess enhanced proteolytic resistance, specificity and potency, making them ideal pharmacological agents. ${ }^{36-38}$ Chief among these targeted therapeutic advances is the ability of cyclic peptides to modulate the previously believed "undruggable" protein-protein interactions (PPI) because of enhanced cellular uptake. ${ }^{36}$

The disruption of the protein-protein interaction between p53 and its negative regulator $\mathrm{Mdm} 2$ comprises one of the most studied areas in cancer therapy. The E3 ubiquitin ligase Mdm2

${ }^{a}$ Institute of Chemical and Engineering Sciences, Agency for Science, Technology and Research, 8 Biomedical Grove, Neuros, \#07-01, Singapore 138665. E-mail: yuenty@ ices.a-star.edu.sg

${ }^{b}$ P53 Laboratory, Agency for Science, Technology and Research, 8A Biomedical Grove, \#06-06, Immunos, Singapore 138648

'Bioinformatics Institute, Agency for Science, Technology and Research, 30 Biopolis Street, \#07-01, Matrix, Singapore 138671

${ }^{d}$ MSD Translational Medicine Research Centre, 8 Biomedical Grove \#04-01, Neuros, Singapore 138665

$\dagger$ Electronic supplementary information (ESI) available. See DOI: $10.1039 / \mathrm{c} 9 \mathrm{sc} 01456 \mathrm{j}$ is overexpressed in a number of cancer cell lines, leading to loss of p53 function and uncontrolled cellular proliferation. ${ }^{37-39}$ Compounds targeting the $\mathrm{p} 53-\mathrm{Mdm} 2$ complex may restore $\mathrm{p} 53$ transcriptional activity by blocking the ubiquitination and proteasomal degradation functions of $\mathrm{Mdm} 2 .^{38,40-44}$ Several classes of molecules have since been developed, mimicking the conserved $\alpha$-helical region of the Mdm2 binding domain of p53. ${ }^{45-48}$

We recently published a series of stapled peptides guided by computer simulations that specifically targeted the p53-Mdm2 binding groove. ${ }^{46}$ These peptides all contained an $i, i+7$ staple and a conserved Phe-Trp-Leu triad which docked inside the hydrophobic cleft of Mdm2. The peptides were synthesised and tested in a T22 p53 reporter assay as a mixture of $E / Z$ isomers. Helically stabilised Mdm2 binding peptide sMTide-02 in particular had demonstrated promising levels of p53 transcriptional response. We reasoned an isomeric mixture was not a requirement for biological activity and that a targeted synthesis of the more active isomer would serve as a more economical manufacturing route.

To our knowledge, an assessment of optimal $E / Z$ isomer ratio has not been critically examined for bioactive stapled peptides. In fact, the lack of available characterisation data has made cross-comparisons and reproduction of biochemical and biological activities difficult. ${ }^{49,50}$ Amongst the growing body of research on $\alpha$-helix stabilisation via $i, i+7$ hydrocarbon stapling, only a handful of studies have looked at the influence of geometric isomerism on $\alpha$-helicity and biological activity. ${ }^{49,51,52}$ The collective published results highlight sequence and targetdependent activity. Wallbrecher et al. reported comparable cellular activity for both $E$ - and Z-ATSP-7041 in SJSA-1 cells. ${ }^{49}$ However in the case of stapled MEP-N, a 2-fold difference in 
antimicrobial activity was observed against Staphylococcus aureus and $E$. coli, with the $Z$-isomer being more effective against the former but less active against the latter. ${ }^{51}$ In this paper, we assess the effects of metathesis conditions (catalyst structure, solvent and temperature) on $E / Z$ selectivity of p53reactivating peptides and provide initial analysis of biophysical and biological properties of the diastereopure, stapled peptide isomers. A synthetic strategy for the attainment of saturated all-hydrocarbon stapled peptides is also presented.

\section{Results and discussion}

\section{Solid-phase peptide synthesis (SPPS) of sMTide-02}

Our first objective was to synthesise the parent peptide sMTide02 using conventional Fmoc solid phase peptide synthesis. ${ }^{23,53}$ Three SPPS conditions were trialled (Fig. 1), exploring different combinations of PEG-based resins (H-Rink Amide ChemMatrix ${ }^{\circledR}$ or H-Ramage ChemMatrix $\left.{ }^{\circledR}\right)$ and activation methods (HATU/DIPEA or HOAt/DIC). Following iterative rounds of amino acid coupling and Fmoc deprotection, the peptide was Ncapped and subjected to several metathesis cycles before TFAmediated cleavage from the resin. Overall, higher yields of crude peptide were obtained with the utilisation of the Ramage resin $\left(0.53 \mathrm{mmol} \mathrm{g}^{-1}\right.$ loading, $50 \%$ yield) as opposed to the recommended Rink Amide resin $\left(0.59 \mathrm{mmol} \mathrm{g}^{-1}\right.$ loading, 36\% yield). ${ }^{23,53}$ HOAt was found to be more soluble in NMP relative to HATU, hence use of HOAt in conjunction with DIC has an added advantage of achieving higher concentrations of the reacting solutions. Despite the same peptide active ester being formed under both coupling conditions, we noted a cleaner reaction profile with the use of HOAt/DIC.

In all cases, 2 pairs of stapled peptide adducts with approximately $1: 1$ ratio could be observed in the HPLC chromatograms. The 2 most intense peaks had identical masses $([\mathrm{M}]+44 \mathrm{Da})$, which corresponded to the unexpected, incomplete decarboxylation of the tryptophan protecting group. Conversely, the masses of the more hydrophobic peaks corroborated well with the expected $\mathrm{m} / \mathrm{z}$ of the desired $E / Z$ olefin isomers. Complete decarboxylation was successfully achieved by overnight treatment of the peptide with aqueous acetic acid followed by lyophilisation. Alternatively, use of side-chain unprotected Trp during SPPS also led to the desired product without oxidation or alkylation of the indole group.

\section{$(E)$-sMTide-02 is more active than $(Z)$-sMtide-02}

Ring closing metathesis (RCM) is a reversible, thermodynamic process that constitutes the key step of stapled peptide synthesis. First propounded by Villemin and Tsuji in $1980,{ }^{\mathbf{5 4 , 5 5}}$ it is now routinely used in macrocycle formations owing to the exceptional functional group compatibility of the olefin metathesis catalysts. Stereoselectivity of the reaction is largely dependent on the degree of conformational strain introduced by the all-hydrocarbon linker. In the case of sMTide-02, stapling led to both $E$ - and $Z$-isomers in almost equal ratios, which is consistent with a previous report. ${ }^{23}$ To further explore the role of olefin geometry on the bioactivity of the stapled peptide, separation of the geometric isomers was attempted by conventional reverse-phase HPLC. After multiple rounds of purification, the two closely-eluting isomers were fully separated.

The geometric configuration of the 2 isomers was determined by ${ }^{1} \mathrm{H}$ NMR spectroscopy. The earlier-eluting isomer of sMTide-02 $\left(t_{\mathrm{R}}^{\prime}=22.12 \mathrm{~min}\right)$ gave an olefinic proton signal at $5.21 \mathrm{ppm}$ with a distinctive, centrosymmetric doublet of triplets splitting pattern $\left[{ }^{3} J(-\mathrm{CH}=\mathrm{CH}-)=11.0 \mathrm{~Hz}\right.$, Fig. S11, ESI $\left.\dagger\right]$ and was assigned the $Z$-configuration. Conversely, the later-eluting

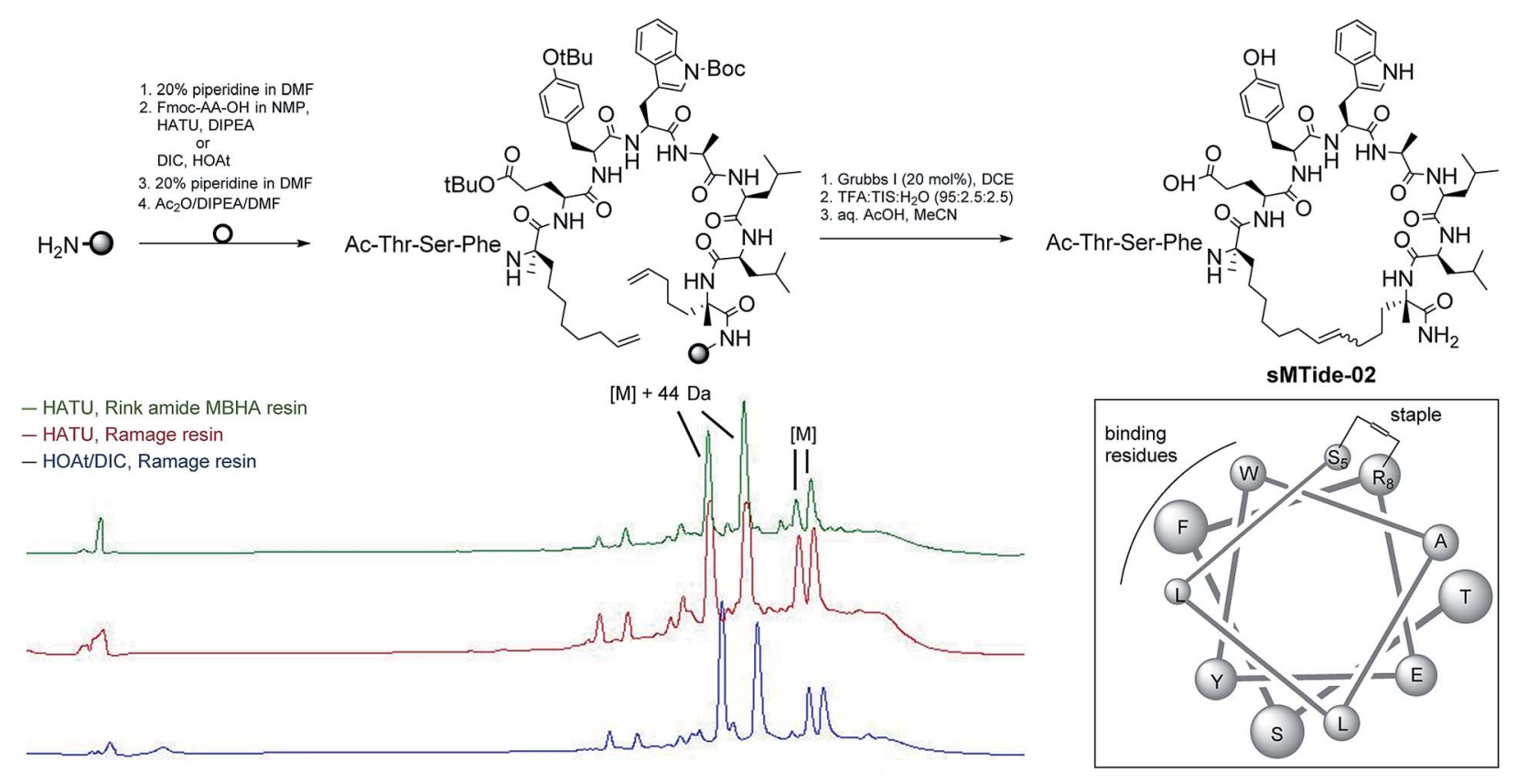

Fig. 1 Fmoc-based solid-phase peptide synthesis (SPPS) and RP-HPLC chromatograms of sMTide-02. 
sMTide-02 isomer $\left(t_{\mathrm{R}}^{\prime}=22.37 \mathrm{~min}\right)$ showed olefinic protons at $5.31 \mathrm{ppm}$ with a ${ }^{3} J$ coupling constant of $15.4 \mathrm{~Hz}$, which corresponded to an E-configuration.

The peptides were assessed for their $\alpha$-helical content and binding affinity to $\mathrm{Mdm} 2$. $\mathrm{P} 53$ reporter and $\mathrm{LDH}$ release assays were also conducted to measure the ability of the peptides to activate p53 in T22 cells and to disrupt cell membranes. The latter assays were performed in the presence of $2 \%$ serum to mimic physiological conditions. As seen from Table 1, cell membranes remained intact after treatment with both geometric forms of sMTide-02 (entries 1-2). In comparison to the $Z$-isomer, (E)-sMTide-02 showed approximately 2-fold improvement in both binding and p53 activation despite similar levels of $\alpha$-helicity.

Additional cell permeable, p53-reactivating stapled peptides were synthesised to increase the test set size (Fig. 2). ATSP-7041, a progenitor of the first stapled $\alpha$-helical peptide entering clinical trials, is a dual inhibitor of MDM2/MDMX developed by Aileron Therapeutics. ${ }^{56}$ VIP82 was previously identified by our research group as ideal for further development (high p53 induction, negligible $\mathrm{LDH}$ release). ${ }^{57}$ It is modelled after the sMTide-02 template sequence and contains solubilising lysine residues at the $\mathrm{N}$-terminus as well as a $\mathrm{C}$-terminal extension (ENF) for additional binding to a secondary pocket of MDM2. ${ }^{58}$ Both peptides, together with sMTide-02, were confirmed to be cell permeable and acting through the specific inhibition of Mdm2. ${ }^{57}$ VIP116 and VIP115, with varying numbers of $\mathrm{N}$ terminal lysine residues, were also synthesised to assess the effects of locally concentrated cationic charges.

As with the case of sMTide-02, all peptides were recovered as $E / Z$-mixtures and the individual isomers were carefully separated by reverse-phase HPLC. Except for ATSP-7041 (entries 3-4) in which the alkene geometry of the isomers could be assigned (Fig. S12, ESI $\dagger$ ), the olefinic protons of remaining peptide pairs (entries 5-10) were not resolved in the ${ }^{1} \mathrm{H}$ NMR spectra. Since we were able to resolve late-sMTide-02 and ATSP-7041 as E-isomers, we believe the late eluting VIP peptides are also $E$ in configuration on the basis that neutralisation of dipole effects would render the $E$-isomer less polar than the $Z$-isomer. For the purpose of this paper, the isomers are defined as early- or lateeluting, according to their adjusted retention times $t_{\mathrm{R}}^{\prime}$.

Except for VIP116 where the late isomer was $\sim 1.8$-fold more efficient in p53 reactivation, no significant differences in p53 activation levels or correlation to $\alpha$-helicity were observed for the remaining peptides pairs. Whilst adjustment of the overall charge from 0 to +2 often leads to enhanced cell permeability of stapled peptides, ${ }^{59}$ we observed in this study that accumulation of localised positive charges can lead to undesired membrane disruption. VIP115, containing 3 consecutive $\mathrm{N}$-terminal lysine residues and a net charge of +1 , gave rise to significant amounts of LDH leakage whereas VIP82 (with 2 N-terminal lysines and

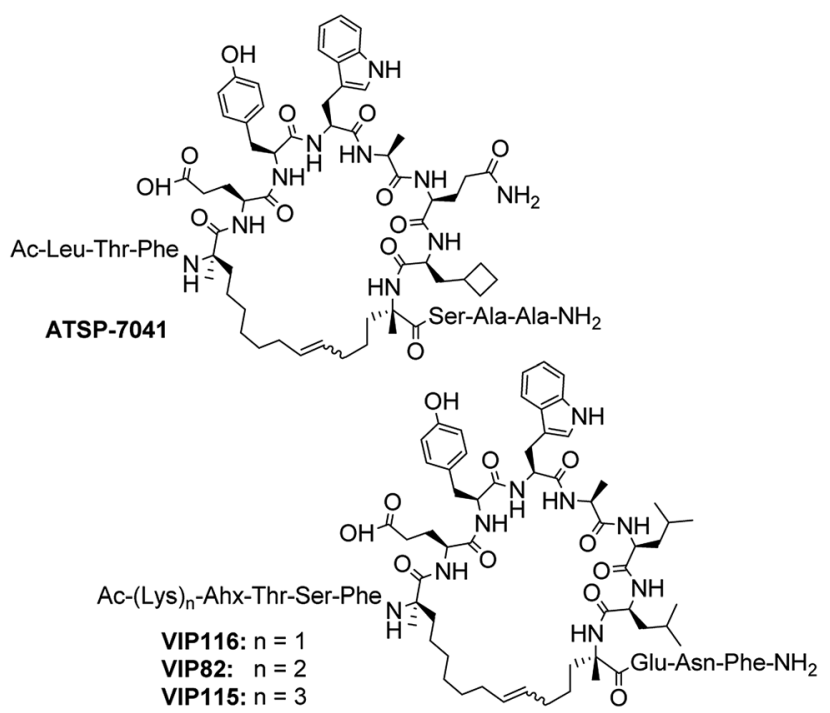

Fig. 2 Structures of ATSP-7041 and lysine-containing, C-terminal extended sMTide-02 analogues.

Table 1 Adjusted retention time $\left(t_{\mathrm{R}}^{\prime}\right)$ determined using the formula $t_{\mathrm{R}}^{\prime}=t_{\mathrm{R}}-t_{0}$; helicity determined by circular dichroism spectroscopy; $k_{\mathrm{d}}$ determined by competitive fluorescence anisotropy titrations; biological activity determined by T22 p53 reporter assay and cell membrane perturbation effects measured using an LDH assay

\begin{tabular}{|c|c|c|c|c|c|c|c|}
\hline Entry & Peptide & $t_{\mathrm{R}}^{\prime}(\min )$ & Net charge & $\alpha$-Helicity & $k_{\mathrm{d}}(\mathrm{nM})$ & $\mathrm{p} 53^{\text {Act }}(\mu \mathrm{M})$ & $\mathrm{LDH}_{50}(\mu \mathrm{M})$ \\
\hline 1 & (Z)-sMTide-02 & 22.12 & -1 & 70.8 & $113.1 \pm 0.01$ & $8.29 \pm 0.19$ & ND \\
\hline 2 & (E)-sMTide-02 & 22.37 & -1 & 72.7 & $63.19 \pm 0.01$ & $3.64 \pm 0.22$ & ND \\
\hline 4 & (E)-ATSP-7041 & 24.44 & -1 & 68.7 & $11.03 \pm 0.01$ & $2.77 \pm 0.23$ & ND \\
\hline 5 & Early-VIP82 & 18.64 & 0 & 28.6 & $94.45 \pm 0.01$ & $4.13 \pm 0.10$ & ND \\
\hline 6 & Late-VIP82 & 18.88 & 0 & 38.5 & $65.47 \pm 0.01$ & $3.38 \pm 0.73$ & ND \\
\hline 9 & Early-VIP115 & 18.09 & +1 & 52.6 & $95.81 \pm 0.01$ & $\sim 3.16$ & $80.99 \pm 1.80$ \\
\hline 10 & Late-VIP115 & 18.25 & +1 & 36.7 & $84.48 \pm 0.01$ & $\sim 2.24$ & $129.8 \pm 15.39$ \\
\hline 11 & Reduced-sMTide-02 & 23.66 & -1 & 71.2 & $209.5 \pm 0.02$ & $1.58 \pm 0.45$ & ND \\
\hline 12 & Reduced-ATSP-7041 & 25.94 & -1 & 69.5 & $112.9 \pm 0.01$ & $2.77 \pm 0.30$ & ND \\
\hline 13 & Reduced-VIP82 & 19.68 & 0 & 41.4 & $215.9 \pm 0.02$ & $3.13 \pm 0.73$ & ND \\
\hline 14 & Reduced-VIP116 & 20.88 & -1 & 52.8 & $113.7 \pm 0.01$ & $5.22 \pm 0.23$ & ND \\
\hline
\end{tabular}


a net charge of 0 ) and other peptides (net charge of -1) activated intracellular p53 with negligible nonspecific cytotoxicity.

\section{Stereoselective synthesis of the late stapled peptide isomer}

Few papers in the stapled peptide literature report the $E / Z$ ratio or discuss the implications of isomerism. ${ }^{\mathbf{4 9 , 5 1 , 5 2}}$ In our case, and likewise observed by Mangold and Grubbs, ${ }^{52}$ no apparent relationship between the helicity and staple isomer type could be observed. Although a previous report has demonstrated negligible differences between the binding and cellular activities of $E / Z$ isomers of related MDM2-binding peptides in SJSA-1 cells, ${ }^{49}$ we observed $\sim 1.6$ to 2.2 -fold improvements in binding and p53 activation for the late isomers of VIP116 and sMTide-02. For this reason, we targeted the synthesis of the more hydrophobic, late isomer of these peptides only.

A previous report had described the synthesis of stereopure $Z$-peptide isomers using chelating ruthenium catalysts. ${ }^{60}$ Stereoselectivity was attributed to steric clash between the catalyst ligands and the approaching olefin. Similarly, by systematically varying different aspects of the existing metathesis protocol, we reasoned that optimum conditions for attaining stapled peptide late isomers could be achieved.

For this study, only ruthenium-based catalysts were considered as molybdenum-based catalysts tend to be air- and moisture-sensitive. Moreover, complete inert conditions are more difficult to achieve in a manual SPPS format. ${ }^{61,62}$ sMTide-02 was used as the model substrate. As illustrated by Table 2 (entry 1), subjection of the linear, side chain-protected peptide to three rounds of olefin metathesis using Grubbs-I catalyst (1) in DCE resulted in $96 \%$ conversion to the desired product with $41 \% E$ selectivity. THF and toluene (entries 2-3) were tolerated by catalyst 1 on resin but resulted in lower conversion and $E$-selectivity.

Use of catalyst 2 afforded stapled sMTide- 02 in $98 \%$ yield after three metathesis cycles, with complete reversal of olefin selectivity (entry 5). In comparison to their Grubbs counterparts, isopropoxy-containing Hoveyda-Grubbs catalysts 3 and $\mathbf{4}$ had lower reactivity but similar diastereoselectivity (entries 7 and 9). For all catalysts tested, increasing the reaction temperature to $50{ }^{\circ} \mathrm{C}$ increased the reaction efficiency but had little impact on stereoselectivity. Notably, the $E / Z$ ratio of the stapled peptide products remained constant from cycle to cycle for all

Table 2 Catalyst effect on E/Z-selectivity of p53-activating stapled peptides
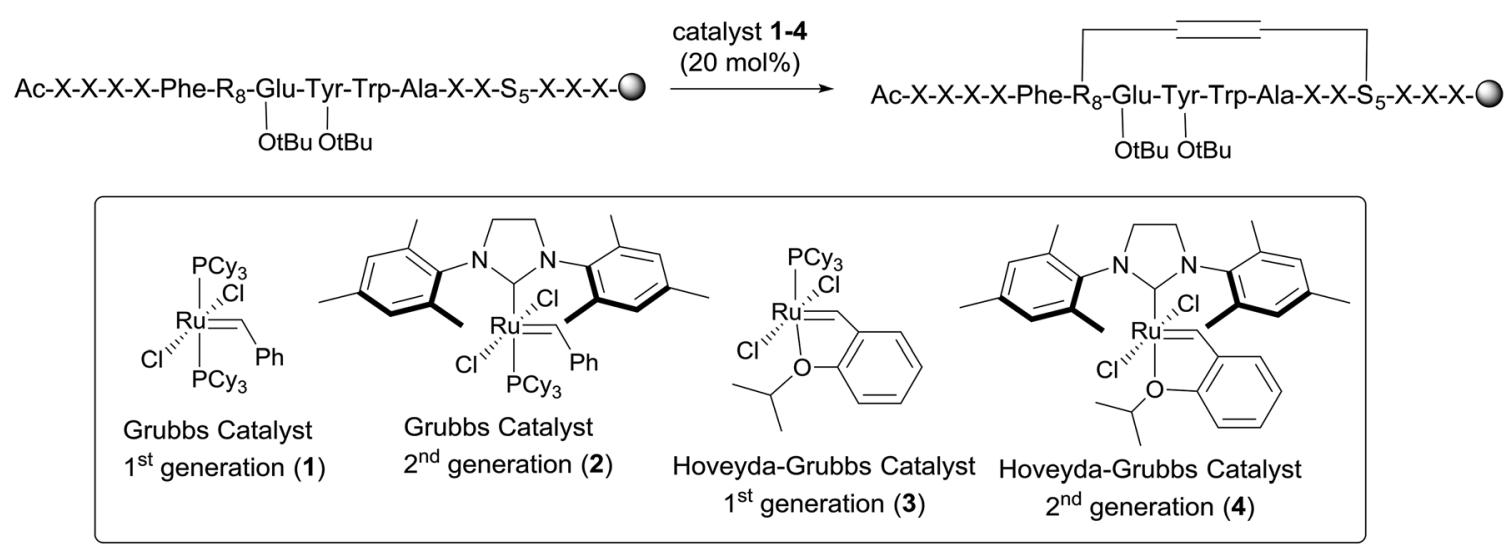

\begin{tabular}{|c|c|c|c|c|c|c|c|c|c|c|}
\hline \multirow[b]{2}{*}{ Entry } & \multirow[b]{2}{*}{ Peptide } & \multirow[b]{2}{*}{ Catalyst } & \multirow[b]{2}{*}{ Solvent } & \multirow[b]{2}{*}{ Temperature } & \multicolumn{3}{|c|}{ Conversion $^{a}(\%)$} & \multicolumn{3}{|c|}{$\begin{array}{l}\text { Selectivity }{ }^{b} \text { (early isomer : late } \\
\text { isomer) }\end{array}$} \\
\hline & & & & & $1 \mathrm{RCM}^{c}$ & $2 \mathrm{RCM}$ & $3 \mathrm{RCM}$ & $1 \mathrm{RCM}$ & $2 \mathrm{RCM}$ & $3 \mathrm{RCM}$ \\
\hline 1 & sMTide-02 & 1 & DCE & $\mathrm{rt}$ & 75 & 92 & 96 & $57: 43$ & $55: 45$ & $59: 41$ \\
\hline 2 & sMTide-02 & 1 & THF & $\mathrm{rt}$ & 31 & 57 & 72 & $67: 33$ & $65: 35$ & $66: 34$ \\
\hline 3 & sMTide-02 & 1 & $\mathrm{PhMe}$ & $\mathrm{rt}$ & 45 & 85 & 92 & $67: 33$ & $64: 36$ & $65: 35$ \\
\hline 6 & sMTide-02 & 2 & DCE & $50{ }^{\circ} \mathrm{C}$ & 98 & $>98$ & $>98$ & $24: 76$ & $21: 79$ & $22: 78$ \\
\hline 7 & sMTide-02 & 3 & DCE & $\mathrm{rt}$ & 20 & 33 & 51 & $61: 39$ & $62: 38$ & $62: 38$ \\
\hline 8 & sMTide-02 & 3 & DCE & $50^{\circ} \mathrm{C}$ & 57 & 82 & 91 & $63: 37$ & $61: 39$ & $59: 41$ \\
\hline 9 & sMTide-02 & 4 & DCE & $\mathrm{rt}$ & 61 & 77 & 85 & $23: 77$ & $24: 76$ & $23: 77$ \\
\hline 10 & sMTide-02 & 4 & DCE & $50{ }^{\circ} \mathrm{C}$ & 87 & $>98$ & $>98$ & $27: 73$ & $25: 75$ & $25: 75$ \\
\hline 11 & ATSP-7041 & 1 & DCE & $\mathrm{rt}$ & N/A & N/A & $>98$ & N/A & N/A & $61: 39$ \\
\hline
\end{tabular}

${ }^{a}$ Percent conversion $=$ product/(product + starting material) as determined by reverse phase HPLC. ${ }^{b}$ Determined by reverse phase HPLC. Early and late isomers of sMTide-02 have $Z$ and $E$ configurations respectively. ${ }^{c}$ Number of RCM cycles. 
catalyst/solvent/temperature combinations trialled. These results imply that certain steps of the metathesis catalytic cycle had been rendered irreversible, most likely due to ethylene loss from agitation of the resin by gas bubbling.

Interestingly, Mangold and Grubbs also observed some of the highest levels of $E$-selectivity when bis-mesityl $N$-heterocyclic carbine-containing ruthenium catalysts 2 and $\mathbf{4}$ were used for $i$, $i+7$ stapling. ${ }^{52}$ The peptides studied were distinctively different: one was venom-derived and two were based on the helical binding domain of the NOTCH transcription factor complex. Macrocycle ring size and inherent activity of the catalyst appear to be the dominant drivers of stereoselectivity, but we cannot completely rule out sequence dependency since side chain interactions will also influence conformational biasing in the transition state.

Given that second-generation catalyst 2 was highly active towards $E$-selective metathesis of sMTide-02, additional experiments were performed on related p53-reactivating stapled peptides. As a direct comparison, ATSP-7041 and VIP116 (representative lysine-containing peptide with a -1 net charge) were treated with both Grubbs first-generation catalyst (1) and the optimised Grubbs second-generation catalyst (2) conditions at $50{ }^{\circ} \mathrm{C}$. Use of catalyst 1 led to $>98 \%$ conversion to stapled ATSP-7041 and VIP116 after 3 metathesis cycles (entries 11 and 13, Table 2), with respective late-isomer selectivity of 39 and $50 \%$. As expected, metathesis with catalyst 2 provided the stapled peptides in $>98 \%$ yield after 2 metathesis cycles, and with an improved $\geq 83 \%$ selectivity for the late isomer (entries 12 and 14, Table 2).

\section{Hydrogenated sMTide-02 is more active than olefinic sMTide- 02}

Thus far, we have attempted to address the inherent isomerism of $i, i+7$ stapled peptides by modulating the product ratio through catalyst control. Perhaps a more straightforward approach would be to remove the isomers altogether. This would also obviate the need for olefin geometry assignment which is often not trivial.

Despite demonstrated successes of sequential macrocyclisation and hydrogenation, from the seminal work of Blackwell and Grubbs to on-resin strategies proposed by Schafmeister and Whelan,,$^{\mathbf{2 0 2 1 , 6 3}}$ a structure search of the literature revealed a single incident of an $i, i+7$ stapled peptide bearing a saturated hydrocarbon bridge. ${ }^{64}$ Moreover, the staple was introduced into the peptide sequence as a pre-assembled diaminodiacid building block and not formed by intramolecular cyclisation of 2 alkenyl groups.

Intrigued by an apparent underutilisation of the two-step metathesis/reduction protocol, we subjected resin-bound $(E)$ sMTide-02 to a transfer hydrogenation and probed the robustness of the literature conditions. We favoured the method outlined by Schafmeister et $a l^{21}$ as the experiment could be conducted on-resin using standard laboratory techniques, without the requirement for sealed tubes or pressure

Table 3 Tandem ring-closing metathesis/hydrogenation study

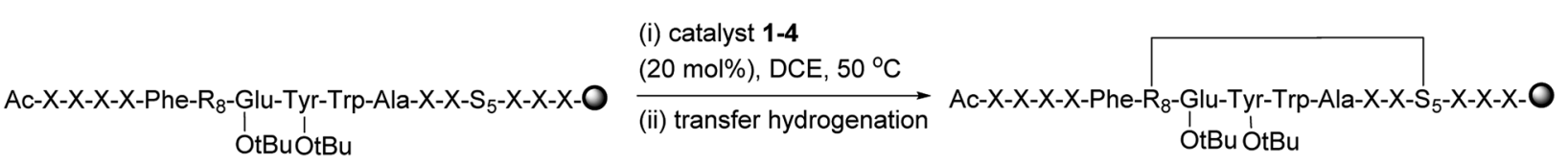

\begin{tabular}{|c|c|c|c|c|c|c|c|}
\hline Entry & Peptide & Catalyst & $\begin{array}{l}\text { Macrocyclisation } \\
\text { conditions }\end{array}$ & $\begin{array}{l}\text { Transfer hydrogenation } \\
\text { conditions }\end{array}$ & \multicolumn{3}{|c|}{ Conversion $^{a}(\%)$} \\
\hline 2 & sMTide-02 & 2 & $2 \mathrm{RCM}, \mathrm{DCE}, 50{ }^{\circ} \mathrm{C}$ & $\mathrm{NaBH}_{4}, \mathrm{MeOH}, \mathrm{rt}$ & 0 & 0 & 6 \\
\hline 3 & sMTide-02 & 2 & $2 \mathrm{RCM}, \mathrm{DCE}, 50^{\circ} \mathrm{C}$ & $\mathrm{NaBH}_{4},{ }^{c} \mathrm{MeOH}, \mathrm{rt}$ & 0 & 0 & 11 \\
\hline 4 & sMTide-02 & 2 & $2 \mathrm{RCM}, \mathrm{DCE}, 50^{\circ} \mathrm{C}$ & $\mathrm{Bu}_{4} \mathrm{NBH}_{4},{ }^{c} \mathrm{MeOH}, \mathrm{rt}$ & 1 & 12 & 42 \\
\hline 7 & sMTide-02 & 2 & $2 \mathrm{RCM}, \mathrm{DCE}, 50^{\circ} \mathrm{C}$ & $\mathrm{PhSiH}_{3}, c$ rt & 1 & 1 & 1 \\
\hline 8 & sMTide-02 & 2 & $2 \mathrm{RCM}, \mathrm{DCE}, 50^{\circ} \mathrm{C}$ & $\mathrm{Ph}_{2} \mathrm{SiH}_{2}{ }^{c}$ rt & 0 & 0 & 0 \\
\hline 9 & sMTide-02 & 2 & $2 \mathrm{RCM}, \mathrm{DCE}, 50^{\circ} \mathrm{C}$ & PMHS, ${ }^{c} \mathrm{rt}$ & 3 & 6 & 11 \\
\hline 10 & sMTide-02 & 2 & $2 \mathrm{RCM}, \mathrm{DCE}, 50^{\circ} \mathrm{C}$ & $\mathrm{Et}_{3} \mathrm{SiH},{ }^{c} 50{ }^{\circ} \mathrm{C}$ & 13 & 45 & 82 \\
\hline 11 & sMTide-02 & 1 & $3 \mathrm{RCM}, \mathrm{DCE}, 50^{\circ} \mathrm{C}$ & $\mathrm{Et}_{3} \mathrm{SiH}^{c}{ }^{5} 5{ }^{\circ} \mathrm{C}$ & 44 & 59 & 84 \\
\hline 12 & sMTide-02 & 3 & $3 \mathrm{RCM}, \mathrm{DCE}, 50^{\circ} \mathrm{C}$ & $\mathrm{Et}_{3} \mathrm{SiH},{ }^{c} 50^{\circ} \mathrm{C}$ & 16 & 31 & 75 \\
\hline 17 & ATSP-7041 & 2 & $2 \mathrm{RCM}, \mathrm{DCE}, 50^{\circ} \mathrm{C}$ & $\mathrm{Et}_{3} \mathrm{SiH},{ }^{c} 50{ }^{\circ} \mathrm{C}$ & $\mathrm{N} / \mathrm{A}$ & N/A & 90 \\
\hline
\end{tabular}

${ }^{a}$ Percent conversion $=$ product $/\left(\right.$ product + starting material) as determined by reverse phase HPLC. ${ }^{b}$ Solvent exchange required. ${ }^{c}$ After each HPLC analysis, an additional aliquot of reagents was added to the reaction mixture. 
equipment. Accordingly, resin-bound, side-chain protected stapled sMTide-02 (synthesised using the optimum conditions from the previous catalyst study) was pre-swelled in NMP then treated with 2,4,6-triisopropylbenzenesulfonyl hydrazide (TPSH) and piperidine at $60{ }^{\circ} \mathrm{C}$ for 2 hours, resulting in the formation of a more hydrophobic species. Despite iterative treatments with fresh reagents, the reaction only proceeded to $39 \%$ conversion (entry 1, Table 3). Nevertheless, the reaction mixture was subjected to reverse-phase purification and sufficient material was attained for bioactivity validation. To our surprise, further improvement in cellular potency was achieved with the saturated form of sMTide-02 (Fig. 3), prompting us to explore whether the hydrogenation effect is applicable to other peptides.

\section{Synthesis of saturated stapled peptides via a one-pot metathesis/transfer hydrogenation}

In light of the experimental findings that saturated stapled peptides may have advantages over the corresponding unsaturated forms, there appears to be an unmet need for an efficient method for their preparation. NHC-containing ruthenium complexes are known to be viable pre-catalysts for the direct and transfer hydrogenation of alkenes, however these systems are generally limited to polarised $\mathrm{C}=\mathrm{C}$ bonds. ${ }^{65}$ More recently, a tandem metathesis/hydrogenation reaction was published by Connolly et al. in which the use of ruthenium metathesis

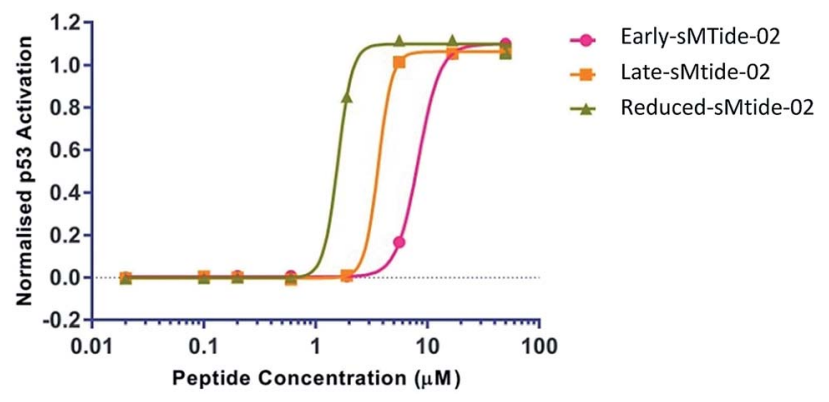

Fig. 3 Titration of sMTide-02 analogues onto T22 p53 reporter cells in the presence of $2 \%$ serum. catalysts in conjunction with sodium borohydride led to the hydrogenation of unactivated alkenes. ${ }^{6}$ Besides the broad reactant scope, the reaction could be carried out in a single pot at ambient temperature. In an attempt to expand the utility of the method, the described solution-phase conditions were carried out on resin.

Following 2 metathesis cycles using catalyst 2 at $50{ }^{\circ} \mathrm{C}$, sodium borohydride ( 2 equivalents) and $\mathrm{MeOH}$ (1/20 volume) were added to the same reaction pot (entry 2, Table 3 ). The reduction of stapled sMTide-02 was monitored by periodic HPLC/MS analysis. After overnight reaction, only trace amounts of the desired product could be detected. Addition of excess reagents (entry 3 ) had no effect on product conversion whereas use of the more soluble tetrabutylammonium borohydride (entry 4) afforded the alkane product in an improved $42 \%$ yield. Increasing the reaction temperature to $50{ }^{\circ} \mathrm{C}$ resulted in faster conversion rates but the reaction had plateaued at $\sim 40-45 \%$ conversion (entry 5).

The mechanism of the transfer hydrogenation likely proceeds via a metal-dihydride species, with sodium borohydride acting as the hydride donor. ${ }^{66}$ Considering that organosilanes are widely employed in SPPS as the reductant in palladium-mediated deallylations, we decided to substitute silanes for tetrabutylammonium borohydride. Our search of the literature revealed precedence for the use of triethylsilane in solid-supported, sequential metathesis/hydrogenation. ${ }^{67,68}$ The microwave irradiation conditions described by Mata and co-workers were optimised for $\alpha, \beta$-unsaturated ester substrates whereas Jida et al. focused on peptides with allylic ethers. To the best of our knowledge, concomitant metathesis/ hydrogenation of internal, unactivated alkenes has not been attempted.

Unlike the borohydride conditions where methanol was added to solubilise the reducing agent, organosilanes can be introduced neat. Evaluation of various silanes revealed triethylsilane to be the optimum reductant (entry 6, Table 3). Use of phenylsilane, diphenylsilane or polymeric PMHS in conjunction with catalyst 2 provided low yielding products (entries 7-9). With all else being equal, increasing the reaction temperature of triethylsilane reduction to $50{ }^{\circ} \mathrm{C}$ drastically increased product conversion from

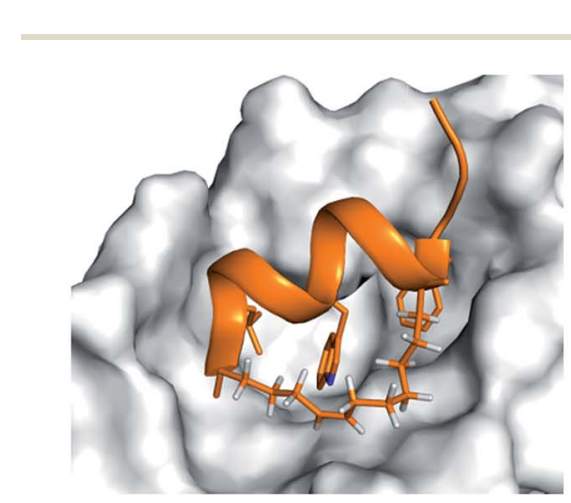

(Z)-sMTide-02: $-65.7 \pm 1.1 \mathrm{kcal} \mathrm{mol}^{-1}$

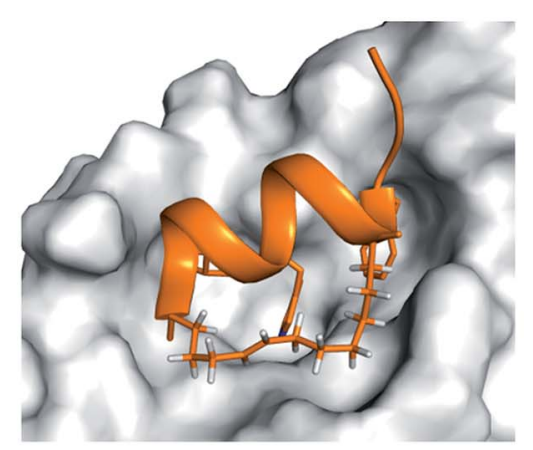

(E)-sMTide-02: $-66.0 \pm 1.8 \mathrm{kcal} \mathrm{mol}^{-1}$

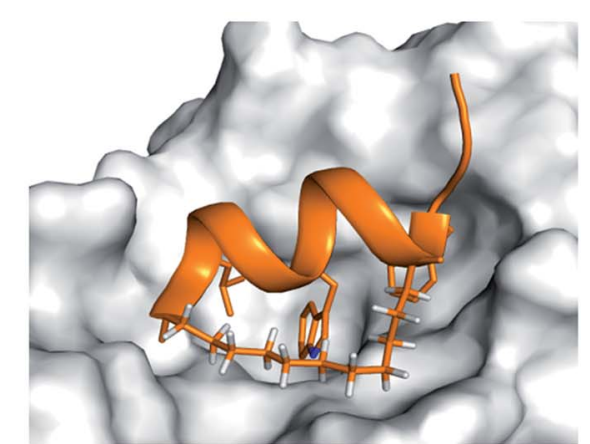

Reduced-sMTide-02: $-65.4 \pm 2.6 \mathrm{kcal} \mathrm{mol}^{-1}$

Fig. 4 Representative MD trajectory structures of sMTide- 02 analogues and their calculated average binding free energies. Entropy change was assumed to be similar between the peptides and therefore omitted from the calculations. 
23 to $82 \%$ (entry 10). To our delight, other common ruthenium metathesis catalysts also demonstrated compatibility with the one-pot metathesis/hydrogenation set up (entries 11-13).

Having identified suitable conditions for the on-resin hydrogenation of sMTide-02, we also examined the utility of the one-pot protocol using stapled VIP116 and ATSP-7041. Both peptides were first subjected to conventional TPSH conditions (entries 14 and 16, Table 3). Again, the reaction had plateaued at $\sim 40 \%$. Under our optimised conditions, hydrogenated VIP116 and ATSP-7041 were obtained in 76 and 90\% yield, respectively (entries 15 and 17).
The peptides, along with reduced VIP82 and VIP115, were subjected to the same biological assays as their unsaturated counterparts (Table 1, entries 12-15). Higher $k_{\mathrm{d}}$ values were observed, but their diminished binding to Mdm2 did not lead to an attenuation in their ability to reactivate p53. In all cases, the reduced analogues exhibited similar \% helicity, $\mathrm{LDH}_{50}$ values and were no less active than the corresponding alkenyl derivatives.

For each peptide trio tested, the reduced form consistently displayed the highest $k_{\mathrm{d}}$ value whereas the late-isomer the lowest. In an attempt to understand the structural basis for these binding results, molecular dynamics (MD) simulations of sMTide-02-
(A)

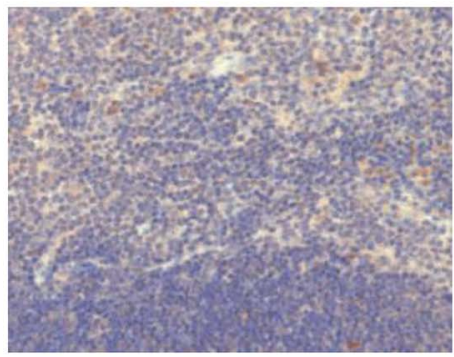

Late-VIP116

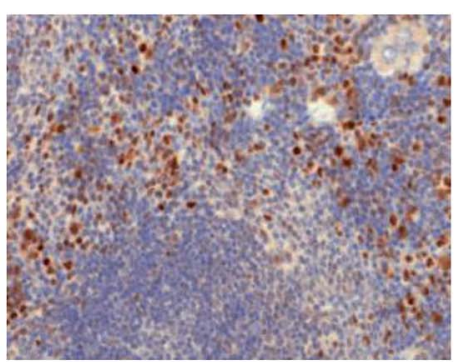

(B)

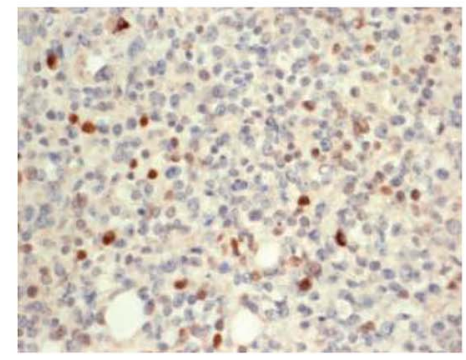

Late-VIP116

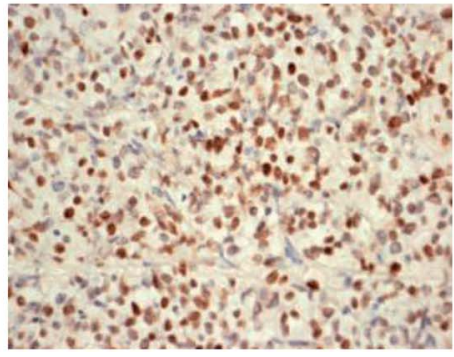

(E)-ATSP-7041

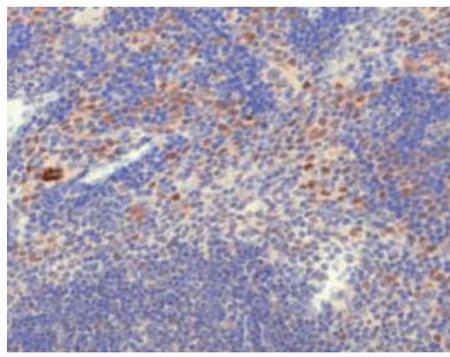

Reduced-VIP116

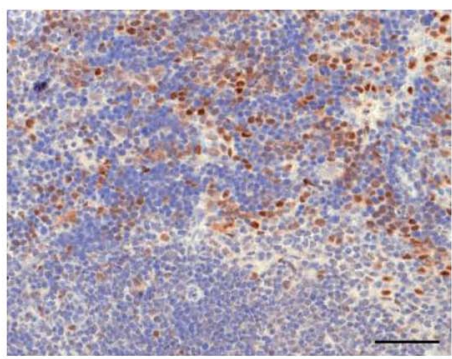

(E)-ATSP-7041

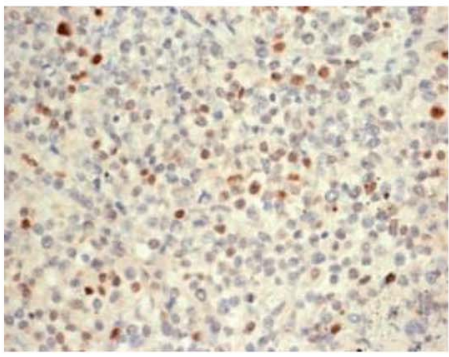

Reduced-VIP116

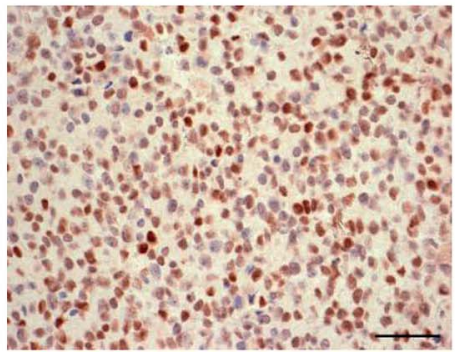

Early-VIP116
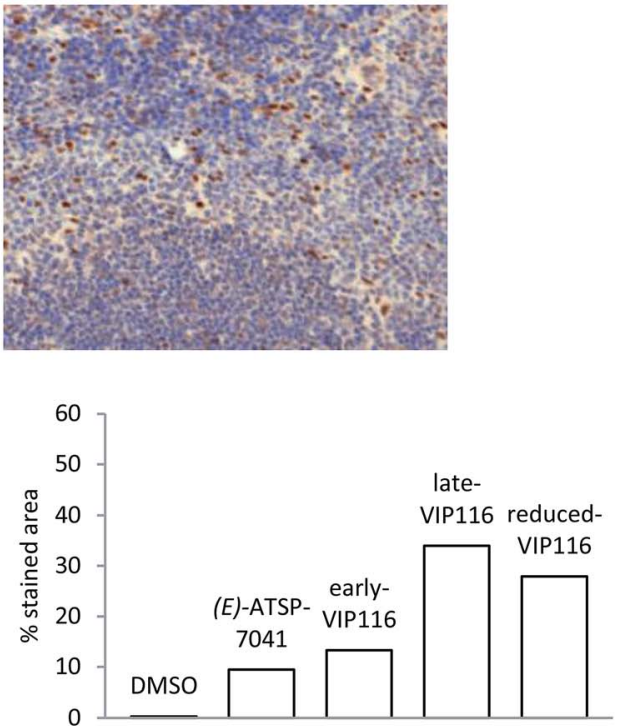

Early-VIP116
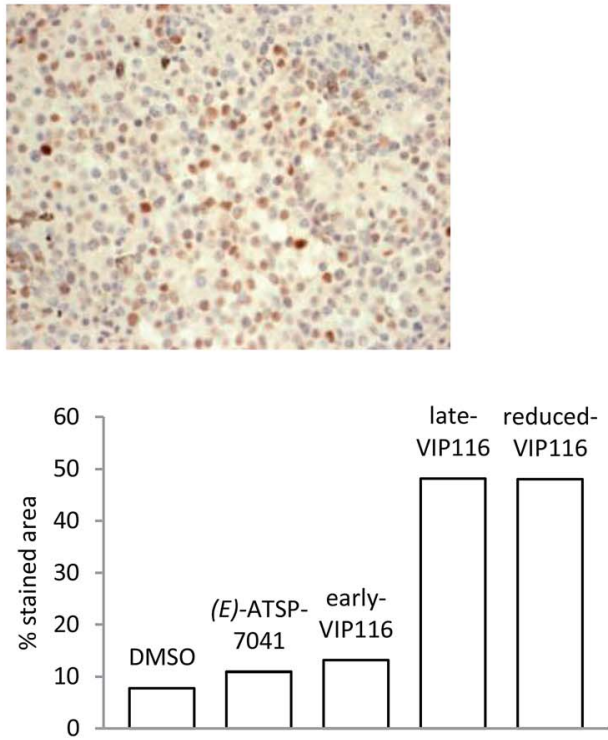

Fig. 5 (A) p53 accumulation in mouse spleen tissues after treatment with VIP116 analogues or controls. (B) p53 accumulation in mouse B16-F10 allograft tumours after treatment with VIP116 analogues or controls. Each image is representative of 5 different images taken of each sample $(n=$ 2-4). Scale bars represent $50 \mu \mathrm{m}$. Immunostaining quantification was performed using inverted images in Image J. ${ }^{70}$ 
Mdm2 complexes were performed. The shortest peptide sMTide02 was chosen to minimise variations in energies due to transient interactions of the flexible peptide regions with Mdm2. The calculated average binding free energies of the isomers were in qualitative agreement with the experimental binding affinity trend (Fig. 4), however the differences were not significant enough for any conclusive structure-activity relationship to be drawn.

\section{Staple effects are more prominent in animal models}

Thus far, we have relied on cellular assays to evaluate the p53 activation efficiency of stapled peptide analogues. By transitioning to animal models, we wished to further validate these findings. Animal studies were conducted using (E)-ATSP-7041 (progenitor of the first stapled peptide in clinical trials, the structure of which was determined using the published X-ray data $^{69}$ ) as the positive control. The solubility of the representative stapled peptides (sMTide-02, VIP116 and ATSP-7041) was assessed by the addition of Hanks' balanced salt solution (HBSS) to peptide solutions in DMSO. All isomers of ATSP-7041 could be dissolved easily. The other stapled peptides immediately precipitated out from solution but upon standing at room temperature with occasional trituration, VIP116 became solubilised in HBSS buffer after 2-3 hours. Hence VIP116 analogues were assessed in the pharmacodynamics study, with $2 \%$ DMSO in HBSS buffer as the vehicle control.

C57BL/6 mice bearing allograft tumour (B16F10 melanoma cells) were administered with the controls or VIP116 peptides (40 $\mathrm{mg} \mathrm{kg}^{-1}$ ) via intraperitoneal injection. 6 hours post injection, spleen and tumour tissues were harvested and p53 stabilisation was detected by immunohistochemistry (IHC) staining (Fig. 5). In the absence of peptide, negligible amount of brown staining was detected in the spleen and a small percentage of positive cell population was observed in tumour tissues. Compared to the vehicle control, mice treated with $(E)$-ATSP7041 and early-VIP116 showed increased p53 expression levels and p53 positive cell population in both spleen and tumour tissues. Late-VIP116 and reduced-VIP116 led to even stronger p53 immunopositive staining. Overall, the allografts results were in good agreement with the spleen samples.

Differences between the in vitro and in vivo data could be observed however. For instance, the p53 ${ }^{\text {Act }}$ values of $(E)$-ATSP7041 and late-VIP116 were roughly the same and about 1.8fold higher than that of early- and reduced-VIP116, but in the allograft tumour model, reduced-VIP116 was found to be as active as late-VIP116 and 4-fold more efficient in reactivating p53 than (E)-ATSP-7041 and early-VIP116. These results cannot be easily explained without further investigation, but are likely due to pharmacokinetics and bioavailability reasons. This also highlights the danger of eliminating compounds based solely on in vitro binding data and the need to develop more predictive tools for cellular uptake and stability for peptide macrocycles.

\section{Conclusions}

We hypothesised that changes in the atomic arrangement of the cross-link of p53-reactivating stapled peptides would have an impact on binding since the hot spot residues resided on one helical face and the chemical brace was oriented towards the protein. Differences in biophysical and biological properties were especially apparent between the $E / Z$-isomers of sMTide-02 and VIP116. We reasoned the late isomer, with improved cellular activity, would be a better candidate to take forward for development. Thus we systematically screened metathesis conditions and found that the use of NHC-containing ruthenium catalysts favoured the formation of the desired, more hydrophobic $i, i+7$ stapled peptide isomer. Notably, isomer differences in VIP116 had a marked effect in animal experiments.

We further established a one-pot metathesis/reduction protocol to generate the corresponding hydrogenated peptides. Introduction of triethylsilane to the metathesis mixture effectively redirected the active ruthenium species to catalyse the hydrogenation of internal, unactivated olefins. Such chemical modifications obviate the often non-trivial tasks of stapled peptide isolation in a fixed ratio or isomer characterisations and might offer a more economical manufacturing route. Despite being the weakest binders, the reduced peptides induced comparable p53 activity to their olefin counterparts in the cellular assays. Again, enhancement in p53 activity was observed in mice for the VIP116 analogue. These observations could not be explained by differences in $\alpha$-helical content but may be a result of favourable membrane translocation due to increased hydrophobicity, ${ }^{71}$ enhanced endosomal escape and/ or p53 activation through binding to Mdmx.

Preliminary results provide sufficient evidence to warrant further investigation of the therapeutic use of sMTide-02 and VIP116 templates which are actively being explored in our laboratory. Our findings also highlight the importance of identifying the impact of $E / Z$ isomer and saturated analogues of all-hydrocarbon stapled peptides. Although this work focused solely on $i, i+7 \mathrm{Mdm} 2$-binding stapled peptides, the chemical strategies presented herein for the modulation of $E / Z$-ratio and one-pot metathesis/reduction are expected to be amenable to other stapled peptides and should be considered for other pathways modulated by $\alpha$-helical stapled peptides.

\section{Author contributions}

T. Y. Y., F. J. F. G. and C. W. J. designed the chemistry experiments. C. J. B., Y. X. and D. P. L. designed the biology experiments. Y. S. T. and C. S. V. designed the computational modelling experiments. F. J. F. G., X. E. L. and N. J. Y. synthesised the peptides. T. Y. Y. and N. J. Y. performed the metathesis and hydrogenation experiments. D. T. carried out T22 p53 reporter, fluorescence anisotropy competition and LDH release assays. Y. X. performed animal studies. H. Y. K. K. and A. W. P. collected the CD spectra. T. Y. Y., C. J. B., Y. X., Y. S. T. analysed the data. T. Y. Y. wrote the paper and all authors contributed to revising the manuscript.

\section{Conflicts of interest}

There are no conflicts to declare. 


\section{Acknowledgements}

This research was funded by the A*STAR JCO Visiting Investigatorship Programme (JCO 1235d00048) and the Industry Alignment Fund (Pre-positioning, HBMS domain H17/01/a0/ 010).

\section{Notes and references}

1 D. Y. Jackson, D. S. King, J. Chmielewski, S. Singh and P. G. Schultz, J. Am. Chem. Soc., 1991, 113, 9391.

2 F. M. Brunel and P. E. Dawson, Chem. Commun., 2005, 20, 2552.

3 A. A. Aimetti, R. K. Shoemaker, C.-C. Lin and K. S. Anseth, Chem. Commun., 2010, 46(23), 4061.

4 A. Muppidi, Z. Wang, X. Li, J. Chen and Q. Lin, Chem. Commun., 2011, 47(33), 9396.

5 C. M. Grison, G. M. Burslem, J. A. Miles, L. K. A. Pilsl, D. J. Yeo, Z. Imani, S. L. Warriner, M. E. Webb and A. J. Wilson, Chem. Sci., 2017, 8(7), 5166.

6 N. Assem, D. J. Ferreira, D. W. Wolan and P. E. Dawson, Angew. Chem. Int. Ed., 2015, 54(30), 8665.

7 Y. Wang and D. H. C. Chou, Angew. Chem., Int. Ed., 2015, 54(37), 10931.

8 Y. Wang, B. J. Bruno, S. Cornillie, J. M. Nogieira, D. Chen, T. E. Cheatham, C. S. Lim and D. H. C. Chou, Chem. - Eur. J., 2017, 23(29), 7087.

9 A. J. Rojas, C. Zhang, E. V. Vinogradova, N. H. Buchward, J. Reilly, B. L. Pentelute and S. L. Buchwald, Chem. Sci., 2017, 8(6), 4257.

$10 \mathrm{~J}$. W. Taylor, Biopolymers, 2002, 66, 49.

11 K. Fujimoto, N. Oimoto, K. Katsuno and M. Inouye, Chem. Commun., 2004, 11, 1280.

12 K. Fujimoto, K. M. Kajino and M. Inouye, Chem. - Eur. J., 2008, $14(3), 857$.

13 M. Kajino, K. Fujimoto and M. Inouye, J. Am. Chem. Soc., 2011, 133(4), 656.

14 G. Lautrette, F. Touti, H. G. Lee, P. Dai and B. L. Pentelute, J. Am. Chem. Soc., 2016, 138(27), 8340.

15 H. G. Lee, G. Lautrette, B. L. Pentelute and S. L. Buchwald, Angew. Chem., Int. Ed., 2017, 56(12), 3177.

16 K. M. Makwana and R. Mahalakshmi, Org. Lett., 2015, 17(10), 2498.

17 L. Mendive-Tapia, S. Preciado, J. García, R. Ramón, N. Kielland, F. Albericio and R. Lavilla, Nat. Commun., 2015, 6, 7160.

18 E. Y.-L. Hui, B. Rout, Y. S. Tan, C. S. Verma, K.-P. Chan and C. W. Johannes, Org. Biomol. Chem., 2018, 16, 389.

19 X. Shi, R. Zhao, Y. Jiang, H. Zhao, Y. Tian, Y. Jiang, J. Li, W. Qin, F. Yin and Z. Li, Chem. Sci., 2018, 9, 3227.

20 H. E. Blackwell and R. H. Grubbs, Angew. Chem., Int. Ed., 1998, 37(23), 3281.

21 C. E. Schafmeister, J. Po and G. L. Verdine, J. Am. Chem. Soc., 2000, $122(24), 5891$.

22 Y.-W. Kim, P. S. Kutchukian and G. L. Verdine, Org. Lett., 2010, 12(13), 3046.
23 Y.-W. Kim, T. N. Grossmann and G. L. Verdine, Nat. Protoc., 2011, 6, 761.

24 J. F. Reichwein, B. Wels, J. A. W. Kruijtzer, C. Versluis and R. M. J. Liskamp, Angew. Chem., Int. Ed., 1999, 38(24), 3684. 25 C. M. Haney, M. T. Loch and W. S. Horne, Chem. Commun., 2011, 47(39), 10915.

26 S. Cantel, A. L. C. Isaad, M. Scrima, J. J. Levy, R. D. DiMarchi, P. Rovero, J. A. Halperin, A. M. D'Ursi, A. M. Papini and M. Chorev, J. Org. Chem., 2008, 73, 5663.

27 M. Empting, O. Avrutina, R. Meusinger, S. Fabritz, M. Reinwarth, M. Biesalski, S. Voigt, G. Buntkowsky and H. Kolmar, Angew. Chem., Int. Ed., 2011, 50(22), 5207.

28 Y. H. Lau, Y. Wu, P. de Andrade, W. R. J. D. Galloway and D. R. Spring, Nat. Protoc., 2015, 10, 585.

29 Y. H. Lau, P. de Andrade, N. Skold, G. J. McKenzie, A. R. Venkitaraman, C. Verma, D. P. Lane and D. R. Spring, Org. Biomol. Chem., 2014, 12(24), 4074.

30 Y. H. Lau, P. de Andrade, S.-T. Quah, M. Rossmann, L. Laraia, N. Skold, T. J. Sum, P. J. E. Rowling, T. L. Joseph, C. Verma, M. Hyvonen, M. L. S. Itzhaki, A. R. Venkitaraman, C. J. Brown, D. P. Lane and D. R. Spring, Chem. Sci., 2014, 5(5), 1804.

31 A. A. Vinogradov, Z.-N. Choo, K. A. Totaro and B. L. Pentelute, Org. Lett., 2016, 18(6), 1226.

32 P. A. Cistrone, A. P. Silvestri, J. C. J. Hintzen and P. E. Dawson, ChemBioChem, 2018, 18(10), 1031.

33 K. Fujimoto, M. Amano, Y. Horibe and M. Inouye, Org. Lett., 2006, 8(2), 285.

34 J. C. Serrano, J. Sipthorp, W. Xu, L. S. Itzhaki and S. V. Ley, ChemBioChem, 2017, 18(12), 1066.

35 P. M. Cromm, S. Schaubach, J. Spiegel, A. Fürstner, T. N. Grossmann and H. Waldmann, Nat. Commun., 2016, 7, 11300.

36 E. M. Driggers, S. P. Hale, J. Lee and N. K. Terrett, Nat. Rev. Drug Discovery, 2008, 7, 608.

37 E. Marsault and M. L. Peterson, J. Med. Chem., 2011, 54, 1961.

38 J. Mallinson and I. Collins, Future Med. Chem., 2012, 4, 1409. 39 C. J. Brown, C. F. Cheok, C. S. Verma and D. P. Lane, Trends Pharmacol. Sci., 2011, 32, 53.

40 C. J. Brown, S. Lain, C. S. Verma, A. R. Fersht and D. P. Lane, Nat. Rev. Cancer, 2009, 9, 862.

41 J. K. Murray and S. H. Gellman, Biopolymers, 2007, 88, 657. $42 \mathrm{M}$. Wallace, E. Worrall, S. Pettersson, T. R. Hupp and K. L. Ball, Mol. Cell, 2006, 23, 251.

43 W. Xue, L. Zender, C. Miething, R. A. Dickins, E. Hernando, V. Krizhanovsky, C. Cordon-Cardo and S. W. Lowe, Nature, 2007, 445, 656.

44 A. Ventura, D. G. Kirsch, M. E. McLaughlin, D. A. Tuveson, J. Grimm, L. Lintault, J. Newman, E. E. Reczek, R. Weissleder and T. Jacks, Nature, 2007, 445, 661.

45 L. T. Vassilev, B. T. Vu, B. Graves, D. Carvajal, F. Podlaski, Z. Filipovic, N. Kong, U. Kammlott, C. Lukacs, C. Klein, N. Fotouhi and E. A. Liu, Science, 2004, 303, 844.

46 C. J. Brown, S. T. Quah, J. Jong, A. M. Goh, P. C. Chiam, K. H. Khoo, M. L. Choong, M. A. Lee, L. Yurlova, 
K. Zolghadr, T. L. Joseph, C. S. Verma and D. P. Lane, ACS Chem. Biol., 2013, 8, 506.

47 S. Shangary, D. Qin, D. McEachern, M. Liu, R. S. Miller, S. Qiu, Z. Nikolovska-Coleska, K. Ding, G. Want, J. Chen, D. Bernard, J. Zhang, Y. Lu, Q. Gu, R. B. Shah, K. J. Pienta, X. Ling, S. Kang, M. Guo, Y. Sun, D. Yang and S. Wang, Proc. Natl. Acad. Sci. U.S.A., 2008, 105, 3933.

48 Y. S. Chang, B. Graves, V. Guerlavais, C. Tovar, K. Packman, K.-H. To, K. A. Olson, K. Kesavan, P. Gangurde, A. Mukherjee, T. Baker, K. Darlak, C. Elkin, Z. Filipovic, F. Z. Qureshi, H. Cai, P. Berry, E. Feyfant, X. E. Shi, J. Horstick, D. A. Annis, A. M. Manning, N. Fotouhi, H. Nash, L. T. Wassilev and T. K. Sayer, Proc. Natl. Acad. Sci. U.S.A., 2013, 110, E3445.

49 R. Wallbrecher, P. Chène, S. Ruetz, T. Stachyra, T. Vorherr and R. Brock, Br. J. Pharmacol., 2017, 174, 2613.

50 F. Wachter, A. M. Morgan, M. Godes, R. Mourtada, G. H. Bird and L. D. Walensky, Oncogene, 2017, 36, 2184.

51 H. Chapuis, J. Slaninová, L. Bednárová, L. Monincová, M. Buděšínský and V. Čeřovský, Amino Acids, 2012, 2047.

52 S. L. Mangold and R. H. Grubbs, Chem. Sci., 2015, 6, 4561.

53 G. H. Bird, W. C. Crannell and L. D. Walensky, Curr. Protoc. Chem. Biol., 2011, 3, 99.

54 D. Villemin, Tetrahedron Lett., 1980, 21, 1715.

55 J. Tsuji and S. Hashiguchi, Tetrahedron Lett., 1980, 21, 2955. 56 F. Meric-Bernstam, M. N. Saleh, J. R. Infante, S. Goel, G. S. Falchook, G. Shapiro, K. Y. chung, R. M. Conry, D. S. Hong, J. S.-Z. Wang, U. Steidl, L. D. Walensky, V. Guerlavais, M. Payton, D. A. Annis, M. Aivado and M. R. Patel, J. Clin. Oncol., 2017, 2505.

57 D. Thean, J. S. Ebo, T. Luxton, X. E. C. Lee, T. Y. Yuen, F. J. Ferrer, C. W. Johannes, D. P. Lane and C. J. Brown, Nat. Sci. Rep., 2017, 7, 1763.

58 Y. S. Tan, J. Reeks, C. J. Brown, D. Thean, F. J. Ferrer Gago, T. Y. Yuen, E. T. L. Goh, X. E. C. Lee, C. E. Jennings,
T. L. Joseph, R. Lakshminarayanan, D. P. Lane, M. E. M. Noble and C. S. Verma, J. Phys. Chem. Lett., 2016, 7, 3452 .

59 L. D. Walensky and G. H. Bird, J. Med. Chem., 2014, 57, 6275. 60 S. L. Mangold, D. J. O'Leary and R. H. Grubbs, J. Am. Chem. Soc., 2014, 136, 12469.

61 R. H. Grubbs, Angew. Chem., Int. Ed., 2006, 45, 3760.

62 G. C. Vougioukalakis and R. H. Grubbs, Chem. Rev., 2010, 110, 1746.

63 A. Whelan, J. Elaridi, M. Harte, S. Smith, W. R. Jackson and A. J. Robinson, Tetrahedron Lett., 2004, 45, 9545.

64 F.-L. Wang, Y. Guo, S.-J. Li, Q.-X. Guo, J. Shi and Y.-M. Li, Org. Biomol. Chem., 2015, 13, 6286.

65 S. Horn and M. Albrecht, Chem. Commun., 2011, 47, 8802.

66 T. Connolly, Z. Wang, M. A. Walker, I. M. McDonald and K. M. Peese, Org. Lett., 2014, 16, 4444.

67 A. A. Poeylaut-Palena, S. A. Testero and E. G. Mata, Chem. Commun., 2011, 47, 1565.

68 M. Jida, C. Betti, P. W. Schiller, D. Tourwé and S. Ballet, ACS Comb. Sci., 2014, 16, 342.

69 Y. S. Chang, B. Graves, V. Guerlavais, C. Tovar, K. Packman, K.-H. To, K. A. Olson, K. Kesavan, P. Gangurde, A. Mukherjee, T. Baker, K. Darlak, c. Elkin, Z. Filipovic, F. Z. Qureshi, H. Cai, P. Berry, E. Feyfant, X. E. Shi, J. Horstick, D. A. Annis, A. M. Manning, N. Fohouhi, H. Nash, L. T. Vassilev and T. K. Sawyer, Proc. Natl. Acad. Sci. U. S. A., 2013, 110(36), E3445.

70 J. Schindelin, L. Arganda-Carreras, E. Frise, V. Kaynig, M. Longair, T. Pietzsch, S. Preibisch, C. Rueden, S. Saalfeld, B. Schmid, J.-Y. Tinevez, D. J. White, V. Hartenstein, K. Eliceiri, P. Tomancak and A. Cardona, Nat. Methods, 2012, 9(7), 676.

71 K. Sakagami, T. Masuda, K. Kawano and S. Futaki, Mol. Pharm., 2018, 15(3), 1332. 